\title{
Mechanisms of constitutive and ATP-evoked ATP release in neonatal mouse olfactory epithelium
}

\author{
Sébastien Hayoz, Cuihong Jia and CC Hegg ${ }^{*}$
}

\begin{abstract}
Background: ATP is an extracellular signaling molecule with many ascribed functions in sensory systems, including the olfactory epithelium. The mechanism(s) by which ATP is released in the olfactory epithelium has not been investigated. Quantitative luciferin-luciferase assays were used to monitor ATP release, and confocal imaging of the fluorescent ATP marker quinacrine was used to monitor ATP release via exocytosis in Swiss Webster mouse neonatal olfactory epithelial slices.

Results: Under control conditions, constitutive release of ATP occurs via exocytosis, hemichannels and ABC transporters and is inhibited by vesicular fusion inhibitor Clostridium difficile toxin A and hemichannel and ABC transporter inhibitor probenecid. Constitutive ATP release is negatively regulated by the ATP breakdown product ADP through activation of P2Y receptors, likely via the CAMP/PKA pathway. In vivo studies indicate that constitutive ATP may play a role in neuronal homeostasis as inhibition of exocytosis inhibited normal proliferation in the OE. ATP-evoked ATP release is also present in mouse neonatal OE, triggered by several ionotropic P2X purinergic receptor agonists (ATP, aßMeATP and Bz-ATP) and a G protein-coupled P2Y receptor agonist (UTP). Calcium imaging of P2X 2 -transfected HEK293 "biosensor" cells confirmed the presence of evoked ATP release. Following purinergic receptor stimulation, ATP is released via calcium-dependent exocytosis, activated P2X $X_{1,7}$ receptors, activated $\mathrm{P} 2 \mathrm{X}_{7}$ receptors that form a complex with pannexin channels, or ABC transporters. The ATP-evoked ATP release is inhibited by the purinergic receptor inhibitor PPADS, Clostridium difficile toxin A and two inhibitors of pannexin channels: probenecid and carbenoxolone.

Conclusions: The constitutive release of ATP might be involved in normal cell turn-over or modulation of odorant sensitivity in physiological conditions. Given the growth-promoting effects of ATP, ATP-evoked ATP release following injury could lead to progenitor cell proliferation, differentiation and regeneration. Thus, understanding mechanisms of ATP release is of paramount importance to improve our knowledge about tissue homeostasis and post-injury neuroregeneration. It will lead to development of treatments to restore loss of smell and, when transposed to the central nervous system, improve recovery following central nervous system injury.
\end{abstract}

\section{Background}

Although once widely assumed that the only source for extracellular ATP was from damaged cells under pathophysiological conditions, it is now accepted that ATP is also released under normal physiological conditions in several organ systems via exocytosis [1], efflux through connexon or pannexin "hemichannels" [2,3], voltage-dependent anion channels [4], and/or activated $\mathrm{P}_{2} \mathrm{X}_{7}$ receptors [1]. Extracellular ATP has numerous functions in sensory systems. It

\footnotetext{
* Correspondence: hegg@msu.edu

Department of Pharmacology and Toxicology, B439 Life Sciences, Michigan State University, East Lansing, Ml 48824, USA
}

is released via pannexins to mediate intercellular communication in taste buds $[2,3]$. In the auditory system, spontaneous ATP release is required for activity in the developing auditory system [5], ATP release through connexin hemichannels propagates calcium signals in the inner ear [6] and purinergic receptor activation by ATP is essential in the cell-cell communication that accompanies cochlear injury [7]. In retinal glial cells, ATP release propagates spontaneous intercellular glial calcium waves that alter the diameter of arterioles in the retina, suggesting released ATP can affect retinal physiology [8].

ATP also mediates essential functions in the olfactory system: (1) ATP activation of purinergic receptors in 
Swiss Webster mouse olfactory epithelium (OE) induces neuroproliferation [9] (2) ATP has proliferative and protective effects following injury $[10,11]$ and (3) ATP induces upregulation and/or release of various neurotrophic factors [12-14]. Given the multiple roles of ATP in the mouse OE, we hypothesized that ATP was released under both normal and pathophysiological conditions in mouse $\mathrm{OE}$ and likely involved multiple mechanisms. Vesicles containing ATP could be released via calcium-dependent exocytosis. Cytosolic ATP could also be released by efflux via ATP binding cassette $(\mathrm{ABC})$ transporters [15,16] expressed in the OE [17]. Several connexin subtypes are expressed in the OE [1822 ] and pannexins are expressed in the olfactory bulb [23], but as of yet, no reports have examined pannexin expression in the epithelium. $\mathrm{P}_{2} \mathrm{X}_{7}$ receptors have been identified in the OE using immunohistochemistry [24]. Thus, there are multiple pathways of ATP release possible in the OE. Determination of ATP release mechanisms is of paramount importance to improve our understanding of the $\mathrm{OE}$ regenerative properties.

The aim of this study was first to investigate whether ATP release mechanisms were present in mouse OE, using Swiss Webster neonatal $\mathrm{OE}$ slices as a model. Using 3 techniques, we showed that ATP is released in neonatal $\mathrm{OE}$ through constitutive and evoked release. We then characterized the mechanisms underlying the two types of ATP release using the luciferin-luciferase assay and the fluorescent ATP marker quinacrine to monitor the loss of ATP fluorescence from endogenous vesicular stores. Our results show that the evoked release of ATP is mediated by purinergic receptor activation and can occur via calcium-dependent exocytosis, efflux of ATP through activated $\mathrm{P}_{2} \mathrm{X}_{7}$ receptors or activated $\mathrm{P}_{2} \mathrm{X}_{7}$ receptor/pannexin complexes, and $\mathrm{ABC}$ transporters. Confocal calcium imaging of $\mathrm{P}_{2} \mathrm{X}_{2}$-transfected HEK293 cells used as biosensors further confirmed the presence of the evoked release of ATP. The constitutive release of ATP does not require purinergic receptor activation, but is mediated by continuous exocytosis and efflux through hemichannels or $\mathrm{ABC}$ transporters. In vivo studies indicate that constitutive vesicular release may play a role in neuronal homeostasis as inhibition of exocytosis inhibited the normal proliferation in the OE. Overall, determination of the ATP release mechanisms in the $\mathrm{OE}$ has identified numerous pharmacological targets to pursue that could modulate neuronal homeostasis.

\section{Results}

Functional purinergic receptors are present in the neonatal olfactory epithelium

Previous reports using immunohistochemistry indicated that $\mathrm{P} 2 \mathrm{X}_{1,3,4,5,7}$ and $\mathrm{P} 2 \mathrm{Y}_{1,2}$ receptors are located in the olfactory epithelium [24-26], while $\mathrm{P}_{2} \mathrm{X}_{2}$ receptors were not located in the OE [26]. Using calcium imaging, we previously showed functional expression of $\mathrm{P}_{2} \mathrm{Y}_{1,2}$ and $\mathrm{P}_{2} \mathrm{X}_{1,3}$ receptors [26], but had not examined for the presence of functional $\mathrm{P} 2 \mathrm{X}_{4,5,7}$ receptors. To determine the most effective agonists to activate purinergic receptors in our neonatal OE slices preparation, we performed calcium imaging using the selective P2 $\mathrm{Y}_{2,4,6}$ agonist UTP $(10 \mu \mathrm{M})$, $\mathrm{P}_{2} \mathrm{X}_{4}$ agonist cytidine 5'-triphosphate (CTP, $\left.100 \mu \mathrm{M}\right)$, P2X ${ }_{1,2 / 3,3}$ agonist $\alpha, \beta$-Methylene ATP $(\alpha \beta$ MeATP, $10 \mu \mathrm{M})$ and $\mathrm{P}^{2} \mathrm{X}_{1,7}$ agonist 2'(3')-O-(4-Benzoylbenzoyl)ATP (BzATP, $50 \mu \mathrm{M}$ ) (Figure 1A and B). For UTP, CTP and BzATP, we recorded from 230 cells located in the apical OE, presumably from sustentacular cell somas. Of the 230 ATP-responsive cells, 99\% (228 cells) responded to UTP, 79\% (181 cells) to Bz-ATP, and 36\% (83 cells) to CTP. The following agonist profile was observed: $\mathrm{ATP}=\mathrm{UTP}>\mathrm{Bz}-\mathrm{ATP}=\mathrm{CTP} \quad(0.66 \pm 0.40, \quad 0.60 \pm 0.36$, $0.43 \pm 0.33$, and $0.34 \pm 0.18 \Delta \mathrm{F} / \mathrm{F} ; \mathrm{p}<0.0001 \mathrm{v}$. ATP, one-way ANOVA with Bonferroni's multiple comparison tests). The $\mathrm{P}_{2} \mathrm{X}_{1,2 / 3,3}$ agonist $\alpha \beta$ MeATP did not elicit a calcium transient in any of the 107 cells examined. This result suggests that $\mathrm{P} 2 \mathrm{X}_{1,3}$ receptors are not readily activated in our imaging experiments and, as such, the BzATP-evoked responses were mediated via $\mathrm{P}_{2} \mathrm{X}_{7}$ as opposed to $\mathrm{P}_{2} \mathrm{X}_{1}$ receptors. Punctate $\mathrm{P} 2 \mathrm{X}_{7}$ receptor
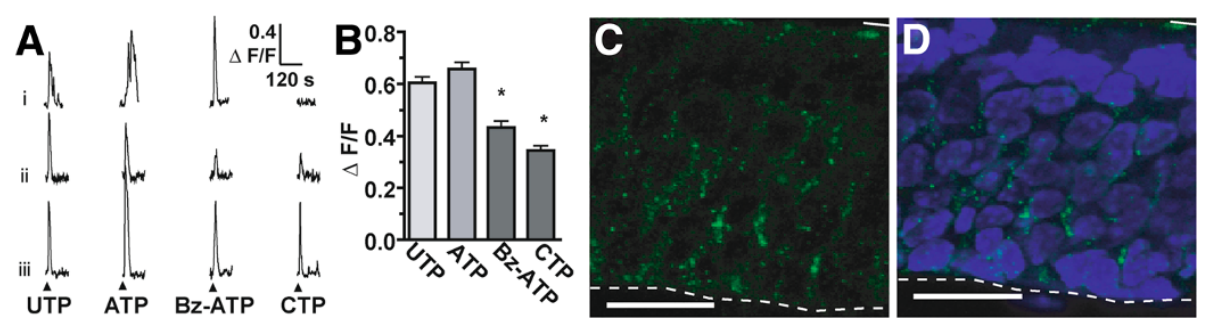

Figure 1 Functional purinergic receptors expressed in the mouse olfactory epithelium. (A) Representative calcium responses from 3 cells (i-iii) elicited by application $(\boldsymbol{\Lambda})$ of P2Y agonist UTP $(10 \mu \mathrm{M})$, P2X and P2Y agonist ATP $(25 \mu \mathrm{M}), \mathrm{P}_{2} \mathrm{X}_{1,7}$ agonist BzATP $(50 \mu \mathrm{M})$, or P2X 4 agonist CTP $(100 \mu M)$. (B) Normalized average peak amplitudes of agonist-elicited calcium responses (mean + SEM). ${ }^{*}$ indicates $p<0.0001 \mathrm{v}$. ATP group with Bonferroni's multiple comparison test). (C-D) Immunoreactivity of P2X (green) and DAPI-labeled nuclei (blue). No immunoreactivity was observed with peptide neutralization or omission of primary antibody. Dashed line, basal lamina; solid line, apical surface of OE. Scale bar: $20 \mu \mathrm{m}$. 
immunoreactivity was observed predominantly in the middle and apical layers of the $\mathrm{OE}$ (Figure $1 \mathrm{C}$ and D), corroborating the Bz-ATP-induced calcium transients. In our previous study [26] calcium responses were recorded from $14 \%$ of the cells following application to $\mathrm{P}_{2} \mathrm{Y}_{1,12,13}$ agonist ADP, 9\% of all cells following application of $\mathrm{P}_{2} \mathrm{X}_{3}$ agonist $\beta, \gamma$-Methylene-ATP, $2 \%$ of all cells following application of P2Y 1,12,13 agonist 2-methylthioadenosine-5'-O-diphosphate, and no cells following application of AMP or adenosine, both ATP degradation products and adenosine receptor agonists. Collectively, these data using selective agonists suggest the presence of $\mathrm{P}_{2,4,6}$ and $\mathrm{P} 2 \mathrm{X}_{1,3,4,7}$ receptors that elicit increases in intracellular calcium that could induce the subsequent release of ATP.

\section{Constitutive and ATP-evoked ATP release occurs in the mouse olfactory epithelium}

We assessed whether ATP is released in the olfactory epithelium under control physiological conditions and following ATP application. Endogenous ATP stores in neonatal $\mathrm{OE}$ slices were labeled with the fluorescent compound quinacrine as previously performed [27]. Quinacrine-labeled ATP stores appear as puncta of fluorescence located throughout the OE (Figure 2A). The individual punctum ranged in diameter between 200 and $250 \mathrm{~nm}$, and sometimes multiple puncta appeared as clusters ranging up to $1.8 \mu \mathrm{m}$ in diameter, suggesting that quinacrine labels ATP that is stored in large vesicles. We visualized the release of ATP from the fluorescent puncta over a period of 400 seconds under physiological conditions (Ringer's solution application; Control) and observed either a linear or an exponential decrease in fluorescence intensity (Figure 2B and Table 1). ATP fluorescence in a region of a quinacrinelabeled slice that was devoid of punctate fluorescence (Figure 2B) showed a minimal change in fluorescence over time, suggesting that the decrease in fluorescence of the puncta is not photobleaching of quinacrine, but rather due to ATP release. Application of $50 \mu \mathrm{M}$ ATP changed the properties of the fluorescent puncta. While some puncta showed an exponential decrease of their fluorescence (Figure 2B, Table 1), fluorescence from other puncta either dynamically fluctuated (Figure 2C, Table 1) or exhibited decreasing fluorescence intensity while the puncta became mobile (Table 1, data not shown). We quantified both the rate of ATP release and the amount of released ATP from all puncta recorded following application of physiological Ringer's solution (control) or $50 \mu \mathrm{M}$ ATP. The rate of ATP release was significantly faster following ATP application compared to control (Figure 2D, $31 \pm 4 \mathrm{~s}$ vs. $304 \pm 27 \mathrm{~s}, \mathrm{n}=11$ puncta from 3 slices and 43 puncta from 3 slices, respectively; $\mathrm{p}<0.0001$, unpaired Student's t-test). In addition, exogenous ATP $(50 \mu \mathrm{M})$ significantly increased the amount of released ATP compared to vehicle control (Figure 2E; $65 \pm 3 \%$ v. $54 \pm 2 \%, \mathrm{p}<0.0001$, unpaired Student's t-test). These data indicate that both constitutive (Ringer's solution application) and evoked (50 $\mu \mathrm{M}$ ATP application) release of ATP occurs in the mouse olfactory epithelium.

To confirm that the decrease in fluorescence from the puncta is due to release of quinacrine-labeled ATP rather than moving out of the focal plane, we assessed both constitutive and evoked release of ATP after $400 \mathrm{~s}$ using confocal $\mathrm{Z}$ stack recordings (see Methods). ATP evoked a significant increase in ATP release compared to control (Figure 2F; $73 \pm 1 \%$ v. $60 \pm 1 \% ; n=124$ puncta from 5 slices and 118 puncta from 5 slices, $\mathrm{p}<0.0001$, unpaired Student's t-test). The amount of ATP released from quinacrine-labeled ATP stores under control or ATP-evoked conditions was statistically similar using both the $\mathrm{Z}$ stack and the time series recording method (Compare Figure $2 \mathrm{E}$ v. 2 F; p $>0.7$, unpaired Student's T tests). These data support the use of $\mathrm{Z}$ stack recording to measure both constitutive and ATP-evoked release of ATP. As this method is devoid of putative artifacts related to a shift of focus over time, we used $\mathrm{Z}$ stack recordings in all subsequent recordings using quinacrine.

ATP release is mediated via purinergic receptor activation We monitored quinacrine-labeled endogenous ATP stores following application of purinergic receptor agonists $\left(50 \mu \mathrm{M}\right.$; Figure $2 \mathrm{~F}$ ). Specific $\mathrm{P}_{2,4,6}$ agonist UTP ( $67 \pm 1 \% ; \mathrm{n}=173$ puncta from 4 slices), $\mathrm{P} 2 \mathrm{X}_{1,2 / 3,3}$ agonist $\alpha \beta M e A T P ~(73 \pm 1 \% ; n=173$ puncta from 5 slices), and $\mathrm{P} \mathrm{X}_{1,7}$ agonist Bz-ATP $(74 \pm 2 \% ; \mathrm{n}=29$ puncta from 5 slices) significantly increased the amount of released ATP compared to control $(60 \pm 1 \% ; \mathrm{n}=118$ puncta from 5 slices; $\mathrm{p}<0.001$, one-way ANOVA, Bonferroni's planned comparisons). The $\mathrm{P}_{2} \mathrm{Y}_{2,4,6}$ agonist UTP released significantly less ATP than ATP and the selective P2X agonists, $\alpha \beta$ MeATP and Bz-ATP $(\mathrm{p}<0.01$, one-way ANOVA, Bonferroni's planned comparisons). These data suggest that ATP evokes the release of ATP through stimulation of multiple purinergic receptor subunits.

To confirm that ATP-evoked ATP release is linked to stimulation of purinergic receptors, we pre-treated $\mathrm{OE}$ slices with either the ectonucleotidase apyrase to degrade extracellular ATP or the non-selective purinergic receptor antagonist PPADS. PPADS pre-treatment ( $5 \mathrm{~min}, 25 \mu \mathrm{M}$ ) did not have an effect on the constitutive release of ATP (Figure 2F; $63 \pm 2 \%, \mathrm{n}=157$ puncta from 3 slices, $\mathrm{p}>0.05 \mathrm{v}$. control, one-way ANOVA, Bonferroni's planned comparisons). However, PPADS pre-treatment significantly inhibited the ATP-evoked release of ATP 

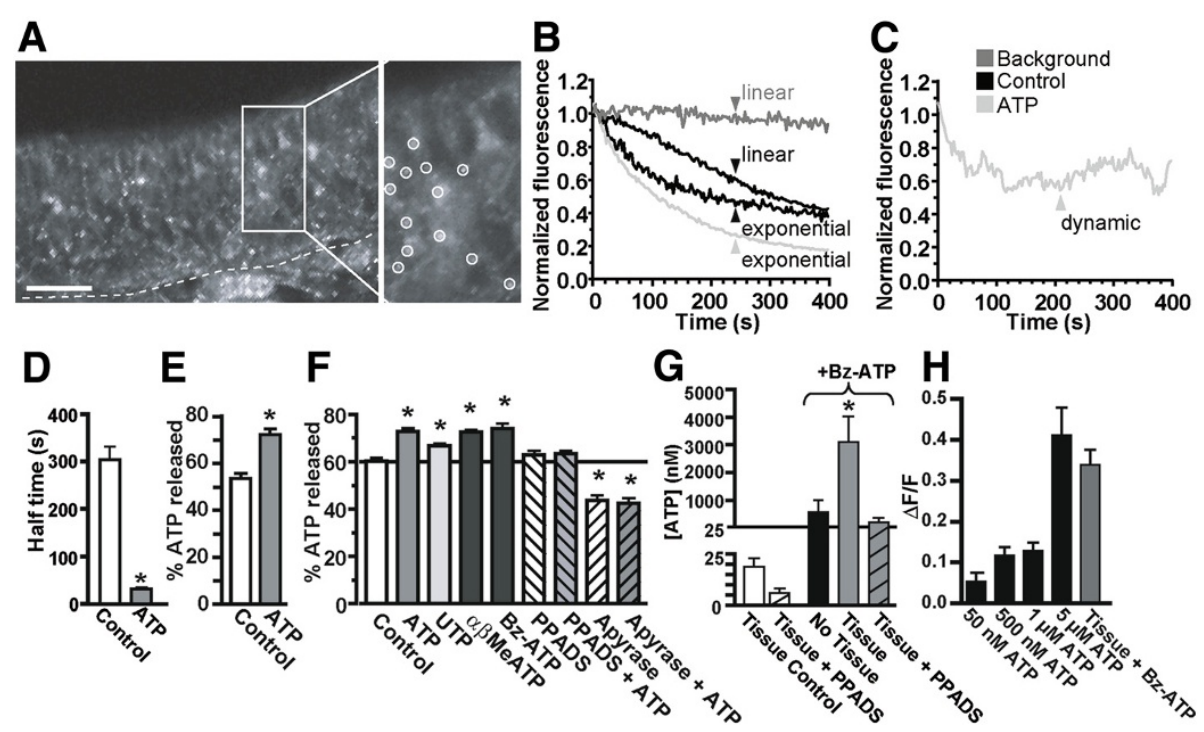

Figure 2 ATP is released both constitutively and by purinergic receptor activation. (A) LEFT: Representative confocal image of quinacrine labeling of endogenous ATP stores located $~ 100 \mu \mathrm{m}$ into the slice. Dashed line, basement membrane. White box indicates region that is expanded to right. Scale bar, $100 \mu \mathrm{m}$. RIGHT: Expanded view of OE showing punctate fluorescent ATP stores. White O's indicate typical puncta selected for further analysis. (B-C) Representative traces of normalized changes in fluorescence over time from individual puncta measured from time-series recordings. (B) Shown are background fluorescence measured in tissue devoid of punctate fluorescence (dark gray), and data that display a linear or exponential decrease in fluorescence recorded in control physiological Ringer's solution (black) or $50 \mu \mathrm{M}$ exogenous ATP (light gray). (C) Representative trace of a punctum displaying dynamic fluctuations in fluorescence recorded following ATP application. Legend pertains to both B and C. (D) Half-time decrease in

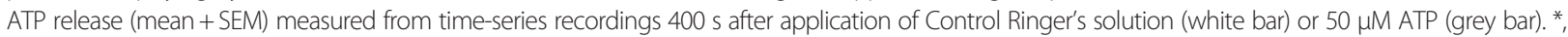
$p<0.0001$ v. control (unpaired Student's t-test). (E) Mean (+ SEM) \% of released ATP measured from time-series recordings after application of Control Ringer's solution or 50 MM ATP. (F) Mean (+ SEM) \% of released ATP measured from Z-stack recordings after application of Control Ringer's solution, $50 \mu \mathrm{M}$ ATP, UTP, aßmeATP, or Bz-ATP, or PPADS $(25 \mu \mathrm{M})$ or apyrase $\left(3\right.$ units $/ \mathrm{ml}, 1 \mathrm{hr}$ pre-incubation) $\pm 50 \mu \mathrm{M}$ ATP. ${ }^{*}, \mathrm{p}<0.01 \mathrm{v}$. Control (one-way ANOVA with Bonferroni's planned comparison test). (G) Luciferin-luciferase assays were used to quantify the amount of constitutively released ATP or evoked ATP release following stimulation with $50 \mu \mathrm{M} \mathrm{P2X}$, receptor agonist Bz-ATP in the absence or presence of neonatal OE tissue slices. ${ }^{*}, \mathrm{P}<0.05 \mathrm{~V}$. Bz-ATP only (one-way ANOVA with Bonferroni's planned comparison test). (H) Peak calcium responses (mean + SEM) elicited from fluo-4 AM loaded P2X $\mathrm{X}_{2}$-transfected HEK-293 cells following stimulation with ATP in the absence of OE tissue $(5 \mu \mathrm{M}, 1 \mu \mathrm{M}, 500 \mathrm{nM}$ or $50 \mathrm{nM})$ or with $50 \mu \mathrm{M}$ Bz-ATP in the presence of an OE slice (Tissue + Bz-ATP). Bz-ATP-evoked calcium transients were not observed in transfected HEK-293 cells in the absence of an OE slice (data not shown).

back to control (Figure 2F; $63 \pm 1 \% ; \mathrm{n}=152$ puncta from 4 slices; $\mathrm{p}<0.001 \mathrm{v}$. ATP, $\mathrm{p}>0.05 \mathrm{v}$. control, one-way ANOVA, Bonferroni's planned comparisons). Incubation with apyrase (1 hour; 3 units $/ \mathrm{ml}$ ) significantly impaired the constitutive release of ATP compared to control conditions (Figure 2F; $44 \pm 2 \%$; $n=90$ puncta from 4 slices; $\mathrm{p}<0.001$, one-way ANOVA, Bonferroni's planned comparison test). In addition, apyrase pre-treatment $(1 \mathrm{hr}, 3$

Table 1 Characteristics of ATP release from quinacrinelabeled ATP stores*

\begin{tabular}{lllll}
\hline & Response & & \multicolumn{2}{l}{ Released ATP } \\
\hline & Control & ATP & Control & ATP \\
Linear decrease & $70 \%(30 / 43)$ & $0 \%(0 / 61)$ & $51 \pm 2 \%$ & - \\
Exponential decrease & $30 \%(13 / 43)$ & $21 \%(13 / 61)$ & $59 \pm 4 \%$ & $82 \pm 3 \%$ \# \\
Dynamic fluctuations & $0 \%(0 / 43)$ & $54 \%(33 / 61)$ & - & $68 \pm 3 \%$ \\
Mobile & $0 \%(0 / 43)$ & $25 \%(15 / 61)$ & - & $45 \pm 6 \%$ \\
\hline
\end{tabular}

*, Data is presented as mean \pm SEM.

$\#, \mathrm{p}<0.001$ Student's t-test. units/ml) significantly impaired ATP-evoked release of ATP to levels that were significantly lower than control (Figure 2F; $43 \pm 2 \%, \mathrm{n}=62$ puncta from 4 slices; $\mathrm{p}<0.001$ v. ATP and control, one-way ANOVA, Bonferroni's planned comparisons). Taken together, our data indicate that ATP evokes release of ATP following purinergic receptor activation.

We next used the luciferin-luciferase assay to quantify the amount of ATP release from neonatal OE slices. Under physiological conditions $19 \pm 4 \mathrm{nM}$ ATP was released from $\mathrm{OE}$ tissue slices (Figure $2 \mathrm{G} ; \mathrm{n}=8$ slices). Although there was a 3 -fold decrease in the amount of ATP released in the presence of non-specific purinergic receptor inhibitor PPADS $(25 \mu \mathrm{M})$, it was not significantly different from control (Figure 2G; $6 \pm 2 \mathrm{nM}, \mathrm{n}=4$ slices, $\mathrm{p}=0.07$, one-way ANOVA with Bonferroni's planned comparison). These data are in agreement with the quinacrine-generated data and suggest that constitutive release is not mediated by purinergic receptors. Application of ATP, a co-factor for luciferase, would 
interfere with the ability to measure endogenously released ATP using the luciferin-luciferase assay. However, the $\mathrm{P}_{2} \mathrm{X}_{1,7}$ receptor agonist Bz-ATP $(50 \mu \mathrm{M})$ induced a low level of bioluminescence corresponding to $576 \pm 424$ nM ATP (Figure 2G; No Tissue (+ Bz-ATP), $\mathrm{n}=5$ slices), allowing the quantification of evoked ATP-release. Bz-ATP $(50 \mu \mathrm{M})$ evoked a significant 5fold increase in bioluminescence in the presence of $\mathrm{OE}$ tissue slices (Figure 2G; Tissue (+ Bz-ATP): $3108 \pm 914 \mathrm{nM}$ ATP, $\mathrm{n}=7$ slices, $\mathrm{p}<0.05 \mathrm{v}$. no tissue, one-way ANOVA with planned comparisons). Significantly more ATP was released from slices stimulated with $50 \mu \mathrm{M} \mathrm{Bz}-$ ATP than from control conditions (Figure 2G; p $<0.01$; one-way ANOVA with planned comparisons). The non-specific purinergic receptor inhibitor PPADS $(25 \mu \mathrm{M})$ significantly inhibited the Bz-ATP-evoked release of ATP to control (no tissue) levels (Figure 2G; $215 \pm 150 ; n=4$ slices; $\mathrm{p}>0.05$, one-way ANOVA with planned comparisons). These data confirm the involvement of $\mathrm{P}_{2} \mathrm{X}_{1,7}$ receptors in the evoked release of ATP.

We next used stable $\mathrm{P}_{2} \mathrm{X}_{2}$-transfected HEK-293 cells as biosensors to further confirm that ATP is released from $\mathrm{OE}$ slices. Fluo-4 AM loaded $\mathrm{P}_{2} \mathrm{X}_{2}$-transfected HEK-293 cells were stimulated with ATP concentrations ranging from $20 \mathrm{nM}$, the concentration of ATP constitutively released from $\mathrm{OE}$ slices as measured by the luciferin-luciferase assay, to $5 \mu \mathrm{M}$, the concentration released from OE slices by Bz-ATP stimulation. ATP application (20 $\mathrm{nM}$ ) was insufficient to elicit an increase in intracellular calcium (data not shown) and 50 nM ATP induced a very small calcium response in fluo-4 AM loaded $\mathrm{P}_{2} \mathrm{X}_{2}$-transfected HEK-293 cells (Figure 2H, $0.05 \pm 0.02 \Delta \mathrm{F} / \mathrm{F}, \mathrm{n}=10$ cells). The mean peak $( \pm \mathrm{SEM})$ ATP response elicited by $5 \mu \mathrm{M}(0.41 \pm 0.07 \Delta \mathrm{F} / \mathrm{F}, \mathrm{n}=15$ cells) was significantly higher than the mean peak amplitudes elicited by all lower ATP concentrations $(1 \mu \mathrm{M}$ : $0.13 \pm 0.02 \Delta \mathrm{F} / \mathrm{F}, \mathrm{n}=13$ cells; $500 \mathrm{nM}$ : $0.12 \pm 0.02 \Delta \mathrm{F} / \mathrm{F}$, $\mathrm{n}=19$ cells, $\mathrm{p}<0.05$, one-way ANOVA with Bonferroni's planned comparison tests). Pretreatment with PPADS $(25 \mu \mathrm{M})$ totally abolished the ATP-induced calcium transients in the $\mathrm{P}_{2} \mathrm{X}_{2}$-transfected HEK-293 cells $(0.01 \pm 0.01$ $\Delta \mathrm{F} / \mathrm{F}, \mathrm{n}=10$ cells from 3 coverslips; data not shown), indicating the calcium increase was mediated by activated $\mathrm{P}_{2} \mathrm{X}_{2}$ receptors. Neither control Ringer's solution nor Bz-ATP $(50 \mu \mathrm{M})$ induced increases in intracellular cal-

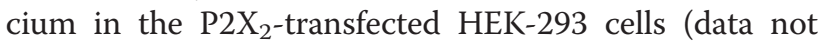
shown). These data suggest that $\mathrm{P} 2 \mathrm{X}_{2}$-transfected HEK293 cells are not sensitive enough to detect constitutively released ATP ( 20 nM, Figure 2F). Indeed, no calcium increases were detected in $\mathrm{P}_{2} \mathrm{X}_{2}$-transfected HEK-293 cells located adjacent to an OE slice in the recording chamber ( $\mathrm{n}=3$ coverslips; data not shown). However, the $\mathrm{P}_{2} \mathrm{X}_{2}$-transfected HEK-293 cells are sensitive enough to detect the evoked release of ATP from $\mathrm{OE}$ slices which is $\sim 3 \mu \mathrm{M}$ (see Figure 2G). In the presence of an OE slice, $50 \mu \mathrm{M}$ Bz-ATP induced a mean ( \pm SEM) calcium transient peak amplitude of $0.34 \pm 0.04$ $\triangle \mathrm{F} / \mathrm{F}$ in the $\mathrm{P} 2 \mathrm{X}_{2}$-transfected HEK-293 cells (Figure $2 \mathrm{H}$, $\mathrm{n}=70$ cells from 3 coverslips). As Bz-ATP did not elicit calcium increases in $\mathrm{P}_{2} \mathrm{X}_{2}$-transfected HEK-293 cells in the absence of $\mathrm{OE}$ tissue, these data indicate that BzATP evokes the release of ATP from OE slices. Note that the calcium response elicited by Bz-ATP stimulation of an OE slice was similar to that elicited by $5 \mu \mathrm{M}$ ATP in the absence of an $\mathrm{OE}$ slice (Figure $2 \mathrm{H}$; p $>0.05$, oneway ANOVA with Bonferroni's planned comparisons). This result suggests that approximately $5 \mu \mathrm{M}$ ATP is released from a slice following stimulation with Bz-ATP and is consistent with the data obtained by the luciferinluciferase assays. Taken together, data obtained from

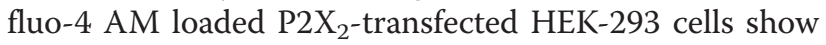
that ATP is released from OE slices following $\mathrm{P}_{2} \mathrm{X}_{1,7}$ purinergic receptor stimulation.

\section{Mechanisms of ATP-evoked ATP release}

We tested the hypothesis that ATP-evoked ATP release in the olfactory epithelium is similar to that in other organ systems and investigated the roles of purinergic receptors, vesicular exocytosis, pannexin/connexin hemi channels and $\mathrm{ABC}$ transporters (see Figure $3 \mathrm{~A}$ for model). Quinacrine imaging was used to investigate vesicular exocytosis as this technique allows visualization of vesicular ATP release, and luminometry assays were used to quantify ATP release for all the proposed mechanisms. Our data support the hypothesis that ATP-evoked release of ATP is mediated predominantly by ionotropic $\mathrm{P} \mathrm{X}_{1,3,7}$ receptors (Figure $2 \mathrm{~F}-\mathrm{H}$ ), but there is evidence that $\mathrm{G}$-protein coupled $\mathrm{P}_{2} \mathrm{Y}_{2,4,6}$ receptors may also be involved (Figure 2F). Activation of either receptor subtype increases intracellular calcium which could induce calcium-dependent exocytosis. Removal of extracellular calcium significantly inhibited ATP-evoked release of ATP (Figure 3B-C; $48 \pm 4 \%, \mathrm{n}=30$ puncta from 4 slices; $315 \pm 34 \mathrm{nM}, \mathrm{n}=7$ slices; $\mathrm{p}<0.05 \mathrm{v}$. ATP or Bz-ATP, Student's t-test). These data further support the involvement of ionotropic $\mathrm{P} 2 \mathrm{X}_{1,3,7}$ receptors, but does not rule out the possibility of a $\mathrm{P}_{2} \mathrm{Y}_{2,4,6}$ receptor contribution. We hypothesized that increases in intracellular calcium following purinergic receptor activation may lead to calcium-dependent exocytosis of ATP stored in vesicles. Pre-treatment with Clostridium difficile toxin A (15 min, $0.5 \mathrm{nM}$ ), known to impair the fusion of vesicles and potently inhibit exocytosis, significantly impaired the evoked release of ATP (Figure 3B-C; $57 \pm 2 \%$, $\mathrm{n}=91$ puncta from 3 slices; $138 \pm 16 \mathrm{nM}$ ATP; $\mathrm{n}=3$ slices; $\mathrm{p}<0.01$ v. ATP or Bz-ATP, one-way ANOVA with Bonferroni's planned comparison tests). In addition, 

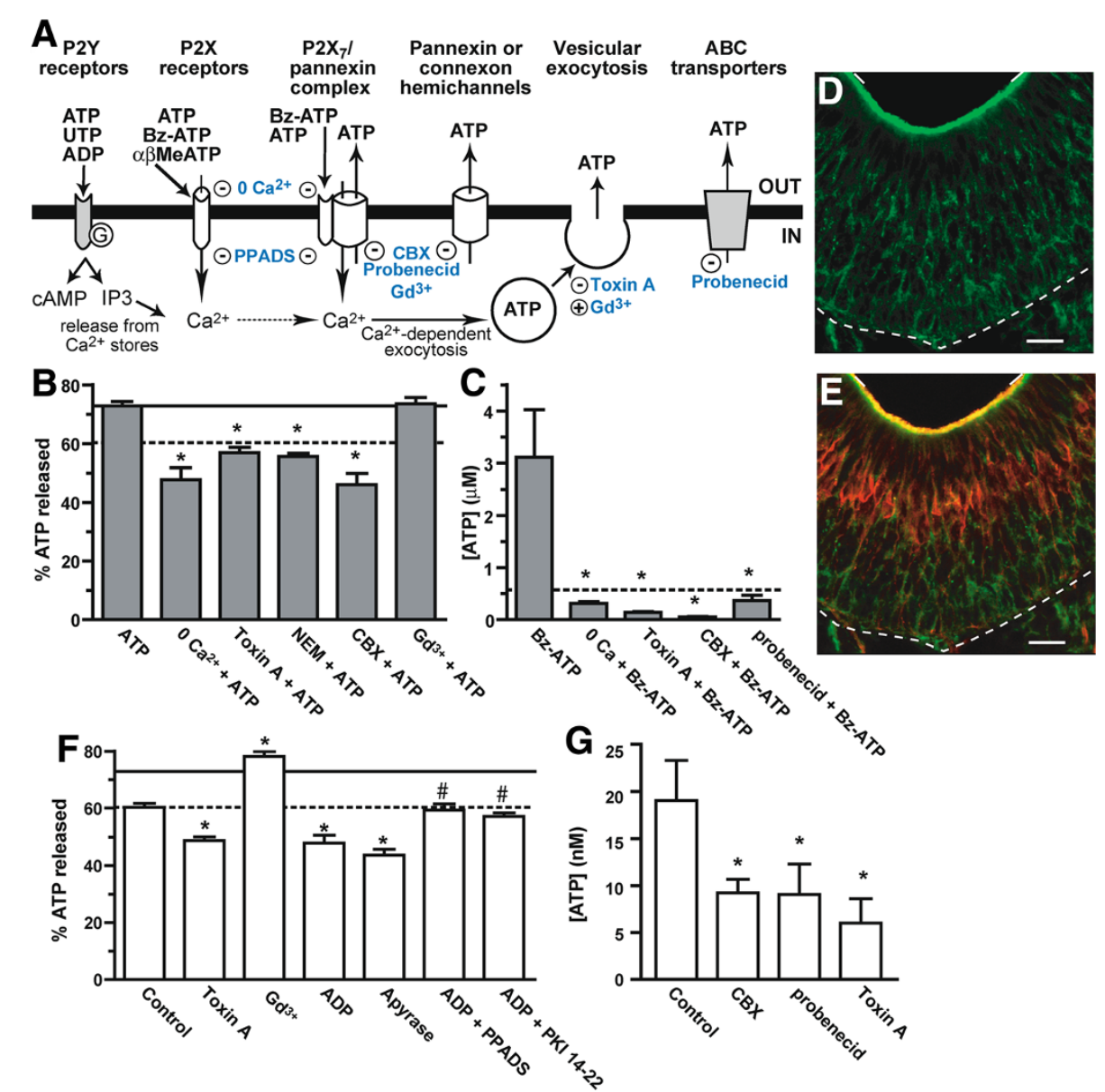

Figure 3 Mechanisms of ATP release. (A) Schematic of the possible mechanisms of ATP release investigated in this study. Extracellular ATP, leaking from damaged cells or released constitutively, activates both $\mathrm{P} 2 \mathrm{Y}$ and $\mathrm{P} 2 \mathrm{X}$ purinergic receptors, leading to increases in intracellular $\mathrm{Ca}^{2+}$ and $\mathrm{Ca}^{2}$ ${ }^{+}$-dependent exocytosis. ATP activated P2X receptors may form a complex with pannexin hemichannels through which ATP can efflux. ATP release may also occur through pannexin/connexin hemichannels or ATP binding cassette (ABC) transporters. Pharmacological inhibitors (-) and stimulators (+) are indicated in blue. (B-C) Measurement of agonist-evoked ATP release. (B) Mean (+ SEM) \% of released ATP measured from Z-stack recordings after application of ATP $(50 \mu \mathrm{M})$ following incubation in Ringer's solution (ATP), media lacking extracellular calcium $\left(0 \mathrm{Ca}^{2+}+\right.$ ATP), non-specific pannexin and activated P2X receptor inhibitor carbenoxolone (100 $\mu \mathrm{M}, \mathrm{CBX}+\mathrm{ATP})$, vesicle fusion inhibitors Clostridium difficile toxin A (30 min, $1 \mathrm{nM}$, Toxin A + ATP) and N-ethylmaleimide (500 $\mu \mathrm{M}, \mathrm{NEM}+\mathrm{ATP})$, or vesicular release stimulator and pannexin and connexin hemichannel inhibitor gadolinium chloride $\left(50 \mu \mathrm{M}, \mathrm{Gd}^{3+}+\mathrm{ATP}\right)$. $^{*}, \mathrm{p}<0.001 \mathrm{v}$. ATP, one-way ANOVA with Bonferroni's planned comparison test. Mean ATP value indicated by solid line; mean control value (see Figure 2F) indicated by dashed line. (C) Luciferin-luciferase assays were used to quantify the amount of ATP released (mean + SEM) following application of $50 \mu \mathrm{M}$ P2X $X_{1,7}$ receptor agonist Bz-ATP in calcium-free solution (0 Ca $\left.{ }^{2+}+B z-A T P\right)$, carbenoxolone (100 $\mu \mathrm{M} ;$; CBX + Bz-ATP), selective pannexin 1 channel and $A B C$ transporter inhibitor probenecid $(500 \mu \mathrm{M})$, or Clostridium difficile toxin A (30 min, $1 \mathrm{nM}$; Toxin A+Bz-ATP). *, p $<0.01 \mathrm{v}$. BzATP, one-way ANOVA with Bonferroni's planned comparison test. Dashed line indicates the mean concentration of ATP measured when $50 \mu \mathrm{M}$ Bz-ATP was used in the assay in the absence of tissue. (D-E) Immunoreactivity of synaptosomal associated protein SNAP-23 (green; D,E) and olfactory marker protein, a marker for neurons (red; E). Dashed line, basal lamina; solid line, apical surface of OE. Scale bar: 20 m. (F-G) Measurement of constitutive ATP release. Confocal Z-stack imaging of quinacrine fluorescence (F) and luciferin-luciferase assays (G) were performed to quantify constitutive ATP release following incubation with Ringer's solution (Control), or various inhibitors: Clostridium difficile toxin A (30 min; $1 \mathrm{nM}$; Toxin A), gadolinium chloride (50 $\mu \mathrm{M}$; $\left.\mathrm{Gd}^{3+}\right)$, probenecid $(500 \mu \mathrm{M})$, carbenoxolone $(100 \mu \mathrm{M} ; \mathrm{CBX})$, ectonucleotidase apyrase (1 h; 3 units/ml), P2Y $1,6,12,13$ agonist ADP $(50 \mu \mathrm{M})$, non-selective purinergic receptor antagonist PPADS and ADP ( $5 \mathrm{~min} ; 25 \mu \mathrm{M}$ and $50 \mu \mathrm{M}$, respectively), or PKA inhibitor protein kinase inhibitor fragment 14-22 (PKI 1422) and ADP (1 hour; $10 \mu \mathrm{M}$ and $50 \mu \mathrm{M}$, respectively). Data reported as described above in Figure 3 B-C. *, p $<0.05$ v. Control; \#, p $<0.001$ v. ADP, oneway ANOVA with Bonferroni's planned comparison test.

$N$-ethylmaleimide, another vesicle fusion inhibitor, significantly inhibited the ATP-evoked release of ATP (Figure 3B; $56 \pm 1 \%, \mathrm{n}=226$ puncta from 3 slices, $\mathrm{p}<0.001$ v. ATP, one-way ANOVA with Bonferroni's planned comparison test). Exocytosis requires formation of soluble $\mathrm{N}$-ethylmaleimide-sensitive factor attachment protein receptor (SNARE) core complexes [28]. We examined the expression of the SNARE complex protein 
synaptosomal associated protein (SNAP)-23. SNAP-23 localized to the thin cytoplasmic extensions throughout the $\mathrm{OE}$ that could be either sustentacular cells or neurons (Figure 3D-E). Taken together, our data indicate that purinergic receptor-mediated calcium-dependent exocytosis evokes the release of ATP.

ATP can also be released through a large non-selective pore formed either by the $\mathrm{P}_{2} \mathrm{X}_{7}$ receptor [29] or by the $\mathrm{P}_{2} \mathrm{X}_{7}$ receptor in a complex with pannexin [30]. To test if ATP or Bz-ATP evokes the release of ATP via a P2X $\mathrm{X}_{7}$ pannexin complex, we used carbenoxolone $(100 \mu \mathrm{M})$, a non-specific pannexin and activated $\mathrm{P}_{2} \mathrm{X}_{7}$ receptor inhibitor [31,32]. Carbenoxolone significantly decreased the amount of ATP released (Figure 3B-C; $46 \pm 4 \%, n=34$ puncta from 3 slices; $56 \pm 9 \mathrm{nM}, \mathrm{n}=3$ slices; $\mathrm{p}<0.01 \mathrm{v}$. ATP or Bz ATP, one-way ANOVA with Bonferroni's planned comparisons). In addition, probenecid (500 $\mu \mathrm{M})$, a selective pannexin 1 channel inhibitor [31,33] as well as an $A B C$ transporter inhibitor [17], significantly decreased the amount of ATP released from slices stimulated by BzATP measured by luminometry (Figure 3C; $365 \pm 106 \mathrm{nM}$, $\mathrm{n}=4$ slices; $\mathrm{p}<0.01$, one-way ANOVA with Bonferroni's planned comparisons). These data indicate that the $\mathrm{P}_{2} \mathrm{X}_{7}$ receptor and pannexin 1 channels, alone or in a complex, and $\mathrm{ABC}$ transporters may also be involved in ATPinduced ATP release.

\section{Mechanisms of constitutive ATP release}

Our data indicated that purinergic receptors are not involved in the constitutive release of ATP based on the lack of an effect on ATP release in the presence of purinergic receptor antagonist PPADS (Figure 2E). Thus, we tested the hypothesis that constitutive ATP release in the olfactory epithelium is similar to that in other organ systems and investigated the role of pannexin/connexin hemi-channels, ABC transporters and vesicular exocytosis (see Figure 3A for models) using both luminometry assays and quinacrine imaging. We measured ATP release in the presence of the non-specific pannexin inhibitor carbenoxolone $(100 \mu \mathrm{M})$. Carbenoxolone decreased the amount of constitutive ATP released by half (Figure 3G, $9 \pm 1 \mathrm{nM}, \mathrm{n}=5$ slices, $\mathrm{p}<0.05 \mathrm{v}$. control, one-way ANOVA with Bonferroni's planned comparison). In addition, the selective pannexin 1 and $A B C$ transporter inhibitor probenecid $(500 \mu \mathrm{M})$ significantly decreased the amount of ATP released from OE slices (Figure 3G; $9 \pm 3$ nM ATP, $\mathrm{n}=4$ slices; $\mathrm{p}<0.05 \mathrm{v}$. control, one-way ANOVA with Bonferroni's planned comparison). Use of vesicular fusion inhibitor Clostridium difficile toxin A (1 nM) significantly impaired the release of ATP compared to control conditions (Figure 3F; $49 \pm 1 \%$, $\mathrm{n}=329$ puncta from 3 slices, $\mathrm{p}<0.001,6 \pm 3 \mathrm{nM}$ ATP; $\mathrm{n}=3$ slices; $\mathrm{p}<0.05$, one-way ANOVA with Bonferroni's planned comparisons). We also used gadolinium chloride
$\left(\mathrm{Gd}^{3+}, 50 \mu \mathrm{M}\right)$ that enhances spontaneous exocytosis in rat brain synaptosomes [34] as well as inhibits pannexin and connexin hemichannels [35]. $\mathrm{Gd}^{3+}$ significantly increased constitutive exocytotic release of ATP (Figure 3F; $78 \pm 2 \%, \mathrm{n}=75$ puncta from 3 slices; $\mathrm{p}<0.001$, one-way ANOVA with Bonferroni's planned comparisons). Note that in the presence of $\mathrm{Gd}^{3+}$, ATP did not significantly enhance the release of ATP compared to $\mathrm{Gd}^{3+}$ alone or ATP alone (Figure 3B, $74 \pm 2 \%$ ATP, $n=49$ puncta from 3 slices, $\mathrm{p}>0.05 \mathrm{v}$. ATP and v. $\mathrm{Gd}^{3+}$, one-way ANOVA with Bonferroni's planned comparisons). These results suggest that exocytotic release of ATP may have a greater role in the constitutive release of ATP than release through pannexin/connexin hemichannels. In addition, $\mathrm{Gd}^{3+}$-evoked vesicular release of ATP may be operating at the maximum extent measurable under physiological conditions as ATP did not enhance the release of ATP in the presence of $\mathrm{Gd}^{3+}$. Alternatively, it may not be possible to observe a greater release of ATP under the quinacrine experimental conditions, and it is not possible to measure the effects using luminometry as the trivalent cation interferes with the luciferinluciferase assay. Overall, our data show that a constitutive release of ATP involves spontaneous exocytosis, $\mathrm{ABC}$ transporters and pannexins in neonatal mouse OE.

We observed that degradation of extracellular ATP by apyrase inhibited the release of ATP to levels even lower than control (Figure 2E). In mouse neuromuscular junction the spontaneous release of neurotransmitters is inhibited by stimulation of the G protein-coupled P2Y purinergic receptors [36]. We hypothesized that in the presence of apyrase, the constitutively released ATP could be degraded to ADP that could inhibit the spontaneous release of ATP via $\mathrm{P}_{2} \mathrm{Y}_{1,12,13}$ purinergic receptor activation. Application of ADP $(50 \mu \mathrm{M})$ significantly impaired the release of ATP (Figure 3F; $48 \pm 3 \%$ ATP, $\mathrm{n}=80$ puncta from 3 slices; $\mathrm{p}<0.0001 \mathrm{v}$. control, unpaired Student's t-test). This result confirms that activation of $\mathrm{P}_{2} \mathrm{Y}_{1,12,13}$ receptor subtypes inhibits the spontaneous vesicular release of ATP. Therefore, blockade of the $\mathrm{P}^{2} \mathrm{Y}_{1,6,13}$ receptors with PPADS should prevent the inhibitory effect of ADP. As expected, following PPADS treatment $(5 \mathrm{~min} ; 25 \mu \mathrm{M})$, the amount of released ATP after ADP stimulation increased significantly and was back to control level (Figure 3F; $59 \pm 2 \% ; \mathrm{n}=78$ puncta from 3 slices; $\mathrm{p}<0.001$ vs. ADP and $\mathrm{p}>0.05 \mathrm{v}$. control, one-way ANOVA, Bonferroni's planned comparison test). Activation of $\mathrm{P}_{2} \mathrm{Y}_{1,12,13}$ receptors by ADP can either activate or inhibit PKA via adenylyl cyclase-mediated cAMP production. We therefore hypothesized that PKA might be involved in the ADPinduced inhibition of spontaneous ATP exocytosis. If ADP inhibits PKA, we would expect that PKA inhibition would have the same effect on spontaneous ATP exocytosis as 
ADP application alone. On the other hand, if ADP activates PKA, the PKA inhibitor should increase the amount of released ATP compared to ADP alone. Incubation with protein kinase inhibitor fragment 14-22 (1 hr, $10 \mu \mathrm{M})$ prevented ADP-mediated inhibition of the spontaneous ATP exocytosis (Figure 3F; $57 \pm 1 \% ; \mathrm{n}=130$ puncta from 3 slices; $\mathrm{p}<0.001 \mathrm{v}$. ADP and $p>0.05 \mathrm{v}$. control, one-way ANOVA, Bonferroni's planned comparison test). Taken together, these data suggest that stimulation of $\mathrm{P}_{2} \mathrm{Y}_{1,13}$ receptor subtypes that lead to PKA activation downregulates spontaneous exocytosis of ATP occurring during the constitutive ATP release in mouse neonate $\mathrm{OE}$.

\section{Constitutive ATP release induces proliferation}

We previously observed that ATP induces neuroproliferation via purinergic receptor activation $[9,10]$. To determine if constitutive ATP release induces neuroproliferation, we examined the effect of Clostridium difficile toxin A, an inhibitor of constitutive release of ATP on cell proliferation in the OE. Neonatal mice were intranasally instilled with either saline vehicle or 1 or $10 \mathrm{nM}$ toxin A. Three days post-instillation, mice were injected with BrdU and $6 \mathrm{~h}$ later tissue was collected to visualize proliferating cells. Clostridium difficile toxin A significantly decreased BrdU incorporation throughout the $\mathrm{OE}$ and in the apical region of the $\mathrm{OE}$ compared to vehicle control (Figure 4: $2.4 \pm 0.6$ v. $17.0 \pm 0.7$ $\mathrm{BrdU}^{+}$cells $/ \mathrm{mm} \mathrm{OE}$ and $0.8 \pm 0.4$ v. $8.0 \pm 0.5 \mathrm{BrdU}^{+}$cells/ $\mathrm{mm}$ apical OE; $\mathrm{p}<0.0001$, unpaired Student's t-test). While we cannot rule out that the toxin might damage the $\mathrm{OE}$, we would expect that cell damage or cell death caused by exposure to Clostridium difficile toxin A should increase BrdU incorporation because of post-injury neuroregeneration. Thus, taken together, this data suggests that constitutive, toxin A sensitiveexocytosis of ATP or another substance induces increased proliferation and may have a role in the normal turnover of both the olfactory sensory neurons and the sustentacular cells.

\section{Discussion}

In this study, we demonstrated the presence of ATPevoked ATP release in neonatal mouse OE slices, and determined the mechanisms underlying this phenomenon. We show that activation of purinergic receptors increases intracellular calcium which could subsequently induce calcium-dependent exocytosis of ATP. Although multiple P2Y and P2X selective purinergic receptor agonists triggered release of ATP, our data suggest that $\mathrm{P} 2 \mathrm{X}_{1,7}$ receptor subtypes play key roles. Indeed, the selective $\mathrm{P} 2 \mathrm{X}_{1,7}$ agonist BzATP significantly increases the exocytotic release of ATP. Only small cations are permeable through the $\mathrm{P}_{2} \mathrm{X}_{7}$ receptor under physiological conditions. However, in the maintained presence of high concentrations of ATP, when divalent cation levels are low, the $\mathrm{P}_{2} \mathrm{X}_{7}$ receptor can either form a non-selective pore [29], or, after complexing with pannexin, form a large pore through which ATP can flow [30]. Bz-ATP is maintained for 30s - $10 \mathrm{~min}$ in these studies, suggesting ample time to open the large pore of the $\mathrm{P}^{2} \mathrm{X}_{7}$ receptor.

In the OE, ATP has been ascribed the functions of neuromodulation, neuroprotection and neuroproliferation by our laboratory and other research groups $[9,10,12,13,26,37,38]$. The evoked release of ATP could be triggered pathologically by the presence of increased extracellular ATP levels because of ATP leaking from damaged cells. Indeed, toxicant exposure depletes intracellular ATP [39], presumably due to released ATP from damaged cells [37]. The evoked release of ATP could play a role in any of these functions. The sustained release of ATP could either induce the neuroprotective expression of heat shock proteins [37], directly stimulate the progenitor cells to proliferate $[9,38]$ and differentiate [9], or act indirectly by promoting the release of other neurotrophic factors [14]. Thus, the results in this study identify the release mechanisms involved in ATPmediated post-injury neuroregeneration.

We previously showed indirectly that constitutive release of ATP might modulate odorant responsiveness of the olfactory sensory neurons [26]. Here, using luciferin-
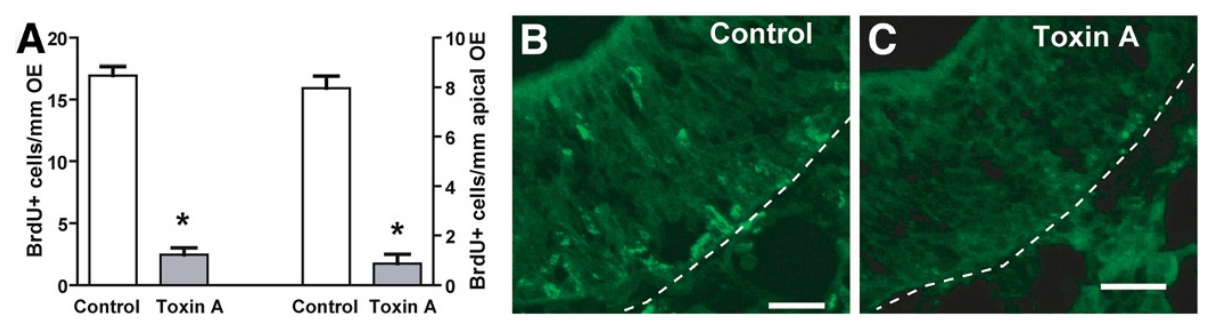

Figure 4 Constitutive exocytotic release induces proliferation in the mouse OE. (A) Quantification of the number of BrdU-immunoreactive cells in the mouse OE and in the apical region of olfactory epithelium (apical OE) 3 days following intranasal instillation with saline (Control) or Clostridium difficile toxin A (Toxin A; $1 \mathrm{nM}$ ). ${ }^{*}, \mathrm{p}<0.001 \mathrm{v}$. control using one-way ANOVA with Bonferroni's planned comparison test. $\mathrm{n}=15$ and 17 sections from 3 and 4 animals for control and toxin A, respectively. (B-C) Representative BrdU immunoreactivity (green) in OE turbinates exposed to saline control (B) or Toxin A (C). Apical region is oriented to the top and the dashed white line represents the basement membrane. Scale bar is $20 \mu \mathrm{m}$. 
luciferase assays, we directly confirm that constitutive release of ATP occurs via exocytosis and efflux through $\mathrm{ABC}$ transporters. We also demonstrate a negative feedback system for constitutive ATP release regulated by ADP, P2Y receptor stimulation and subsequent activation of PKA. The exact mechanism of constitutive ATP release inhibition is still unknown. To our knowledge, direct inhibition of exocytosis or $\mathrm{ABC}$ transporters does not involve PKA. P2Y receptor activation inhibits spontaneous vesicular release of acetylcholine in the mouse neuromuscular junction, but does not require PKA [36,40]. ADP is rapidly degraded to adenosine. Our previous work suggests that adenosine receptors are not expressed in the olfactory epithelium: we observed no responses to adenosine or AMP during confocal calcium recordings [26]. However, adenosine may modulate ADP's activation of P2Y receptors to regulate constitutive ATP release.

We also postulate that constitutively released ATP might play a role in neuronal homeostasis in the OE. Purinergic receptor activation induces cell proliferation [9], has post-injury proliferative and protective functions [10], and elicits upregulation and/or release of many different neurotrophic factors [12-14]. Here, we show constitutive exocytosis may induce cell proliferation. Neuronal homeostasis must be tightly regulated to prevent over-stimulation of cell proliferation. The P2Y receptor-mediated inhibition of the constitutive release of ATP would provide negative regulation. Further support for this negative feedback system is provided by the observation that basal progenitor cells of the OE express ectonucleotidases [41]. This provides a mechanism to degrade ATP to ADP, preventing excessive stimulation of $\mathrm{P}_{2} \mathrm{Y}_{2}$ receptors present on the proliferative basal progenitor cells [26], and inhibiting the constitutive release of ATP. Thus, there is local regulation of constitutive ATP release.

\section{Conclusions}

We describe constitutive and purinergic receptor-mediated ATP-evoked ATP release via calcium-dependent vesicular exocytosis, pannexin/connexin hemichannels and $A B C$ transporters. Overall, the demonstration that extracellular ATP can elicit ATP release provides a novel pathway with potential pharmacological targets to explore mechanisms of neuroregeneration and that have ramifications for the CNS. Likewise, the role of constitutive release of ATP in neurogenesis under physiological conditions may be utilized to promote neuroregeneration following cell injury in neurodegenerative disease and spinal cord injury.

\section{Methods}

Solutions

All chemicals were purchased from Sigma-Aldrich (St. Louis, MO, USA) unless noted.
Ringer's solution contained (in $\mathrm{mM}$ ) $140 \mathrm{NaCl}, 5 \mathrm{KCl}$, $1 \mathrm{MgCl}_{2} 6 \mathrm{H}_{2} \mathrm{O}, 2 \mathrm{CaCl}_{2}, 10$ HEPES, 10 glucose (pH 7.4). Calcium-free Ringer's solution contained (in mM) 140 $\mathrm{NaCl}, 5 \mathrm{KCl}, 10$ HEPES, 4 EGTA, and 20 glucose (pH 7.4). All solutions used in the quinacrine experiments contained probenecid $(500 \mu \mathrm{M})$, an anionic transporter inhibitor, to aid in retention of quinacrine [42]. Ethanol and dimethylsulfoxide interfered with both the quinacrine and the luciferin-luciferase assays, and thus only inhibitors that soluble in Ringer's solution were used in these studies. Concentrated stock solutions of ATP, UTP, cytidine 5'-triphosphate (CTP), 2'(3')-O-(4-benzoylbenzoyl)adenosine 5 '-triphosphate (Bz-ATP), $\alpha, \beta$-methylene adenosine 5 'triphosphate $(\alpha \beta$ MeATP), pyridoxalphosphate-6-azophenyl-2',4'-disulfonate (PPADS), apyrase, N-ethylmaleimide, and Clostridium difficile toxin A were made in Ringer's solution, stored at $-20^{\circ} \mathrm{C}$ and, on the day of the experiment, diluted to concentration values indicated in the text. Fresh stock solution of carbenoxolone dissolved in Ringer's solution was made on the day of the experiment and diluted to concentration values indicated in the text.

\section{Cell and tissue and culture}

Olfactory epithelial slices $(400-500 \mu \mathrm{m})$ were prepared from Swiss Webster neonatal mice (Charles River, Portage, MI) as previously described [26]. All animal procedures were approved by Michigan State University's IACUC, and all applicable guidelines from NIH were followed. P2X $\mathrm{X}_{2}$-transfected human embryonic kidney (HEK293) cells were generously provided by Dr. James Galligan from Michigan State University [43]. They were grown in Dulbecco's modified Eagle's medium (DMEM) F-12 containing 10\% fetal bovine serum, 10\% GluMax (Invitrogen, Carlsbad, CA, USA), and 100 units $\mathrm{mL}^{-1}$ penicillin and streptomycin. Cells were passaged once every 3 days when they reached $90 \%$ confluence. Afterwards, cells were plated on $35 \mathrm{~mm}$ coverslips and maintained at $37^{\circ} \mathrm{C}$ $\left(5 \% \mathrm{CO}_{2}\right)$ for $24 \mathrm{~h}$ before use in calcium imaging experiments. For each treatment group 3 coverslips were used.

\section{Bioluminescence detection of ATP released from olfactory epithelium slices}

ATP was quantified using $0.5 \mathrm{mM}$ D-luciferin and $4 \mu \mathrm{g} / \mathrm{ml}$ luciferase in Ringer's solution obtained from an ATP determination kit (Molecular Probes, Eugene, OR). Luminescence, in relative light units, was recorded continuously with 1-s photon collection intervals using a Turner TD20/20 $/ 0^{\mathrm{n}}$ luminometer. Standard curves of ATP (Mg salt) ranging between $10 \mathrm{nM}-5 \mu \mathrm{M}$ and made using serial dilution from a $0.5 \mathrm{M}$ ATP stock were recorded daily in $200 \mu \mathrm{l}$ luciferin and luciferase solution. The ATP standard curves were linear in the range of $10 \mathrm{nM}-5 \mu \mathrm{M}$ 
$\left(r^{2}: 0.93-0.99\right)$. Individual OE slices $(500 \mu \mathrm{m})$ were placed in a $200 \mu \mathrm{l}$ bolus of luciferin and luciferase solution in a $35 \mathrm{~mm}$ petri dish and ATP release rates measured in presence or absence of inhibitors. In order to measure purinergic-evoked ATP release using the luciferinluciferase assay, the purinergic agonist should not act as a substrate or co-factor for luciferase. We tested the ability of Bz-ATP, UTP and CTP to produce luminescence in the luciferin-luciferase assay. Bz-ATP $(50 \mu \mathrm{M})$ induced the smallest increase in luminescence when applied alone to the luciferin and luciferase solution, corresponding to $\sim 500 \mathrm{nM}$ ATP, whereas UTP and CTP induced a response that corresponded to $5 \mu \mathrm{M}$ ATP. In pilot studies, the luminescence baseline was stabilized at $t=10$ minutes after a slice or Bz-ATP was put into the luciferin and luciferase solution. Therefore, all data were analyzed at 10 minutes by converting the raw relative light unit values to concentration of ATP using the standard curve (relative light units v. ATP concentration $(\mu \mathrm{M})$ ) and interpolation from a linear regression (Prism Software 5.01, Graphpad Software; San Diego, CA). Note that the estimated concentration of released ATP (into $200 \mu \mathrm{l}$ ) is likely to be an underestimate of the amount released into the microenvironment of the tissue. At the end of each experiment, as a positive control, a bolus of Triton X-100 was added ( $0.5 \%$ final concentration) to release ATP via lysis of the cells.

\section{Confocal imaging of fluorescent ATP stores}

OE slices were incubated for $30 \mathrm{~min}$ at room temperature $\left(23^{\circ} \mathrm{C}\right)$ in Ringer's solution with quinacrine $(5 \mu \mathrm{M})$. Note the diameter of fluorescent punctum $(\sim 200-250 \mathrm{~nm})$ that resulted from quinacrine loading was within the optical resolution of confocal fluorescent microscopy. Recordings were performed at a depth of at least $100 \mu \mathrm{m}$ to avoid damage using an Olympus Fluoview 1000 system (Olympus, Center Valley, PA) [44] and a superfusion flow rate of $1.0 \mathrm{ml} / \mathrm{min}$. A static bath in which agonist or inhibitor were added directly to the bath was used in a few cases due to excessive movement of the slice ( $\mathrm{n}=6$ slices). No statistical differences were observed between results recorded in a static or superfused bath (Table 2). Therefore, additionally, to minimize the application of select inhibitors in limited supply, experiments using the ectonucleotidase apyrase and Clostridium difficile toxin A were performed in a static bath. Quinacrine was excited at $488 \mathrm{~nm}$ and fluorescence was detected at 510-525 nm. Images ranged from $512 \times 512$ pixels to $1600 \times 1600$ pixels.

Time series experiments were performed at $\geq 1 \mathrm{~Hz}$ and data were collected for $400 \mathrm{~s}$, the time required for the fluorescence decrease of most of the puncta recorded in control condition (Ringer's application) to reach a plateau. For each punctum, the percentage of released ATP was determined as $100^{*}\left[1-\left(\mathrm{F} / \mathrm{F}_{0}\right)\right]$, where $\mathrm{F}_{0}$ is the mean fluorescence of the first 10 frames and $F$ is the fluorescence remaining after $400 \mathrm{~s}$. We also calculated the halftime of ATP fluorescence by fitting the change in fluorescence over time with a non-linear regression function (exponential decay) or linear regression function (linear decay). We analyzed only puncta with linear or exponential fluorescence due to the irregularity of the dynamic and mobile puncta.

Z-stack recordings were also performed to minimize changes in the fluorescence of quinacrine-labeled ATP inherent with imaging thick tissue. We recorded for a duration of $500 \mathrm{~s}$ by collecting 5 consecutive Z-stacks per slice, each with a duration of $100 \mathrm{~s}$. Ringer's solution or pharmacological compounds were applied at the beginning of the second Z-stack (i.e., at 100 s). In Z-stack recordings, only one focal plane was selected for further analysis based on the ability to distinguish the same cell morphology in relationship to the same puncta of fluorescence within the one focal plane throughout the $500 \mathrm{~s}$ recording. For each punctum, the percentage of released ATP was determined as $100^{*}\left[1-\left(\mathrm{F} / \mathrm{F}_{0}\right)\right]$, where $\mathrm{F}_{0}$ is the fluorescence of the punctum in the focal plane of the first $\mathrm{Z}$ stack (i.e., $\mathrm{t}=0-100 \mathrm{~s}$, depending on the focal plane selected) and $F$ is the fluorescence remaining in the punctum of the same focal plane of the last $\mathrm{Z}$ stack, (i.e., $t=400-500 \mathrm{~s}$, depending on the focal plane selected). Note the Z-stack F value is measured $\sim 400 \mathrm{~s}$ following agonist application to correspond as closely as possible to the time-series experiments. Baseline fluorescence intensity did not vary between slices immediately following quinacrine loading and following long incubations with control Ringer's solution or inhibitors. Therefore, there were no adjustments made to

Table 2 Comparison of ATP release in different experimental conditions*

\begin{tabular}{|c|c|c|c|c|c|}
\hline \multirow[t]{2}{*}{ Treatment } & \multicolumn{2}{|l|}{ Superfused bath } & \multicolumn{2}{|l|}{ Static bath } & \multirow{2}{*}{$\begin{array}{l}\text { Significance } \\
\text { (Student's } \\
\text { t test) }\end{array}$} \\
\hline & $\bar{n}$ & Released ATP* & $\mathrm{n}$ & Released ATP* & \\
\hline Control (Ringer's) & 89 puncta, 3 slices & $65 \pm 1 \%$ & 80 puncta, 3 slices & $66 \pm 2 \%$ & $p=0.61$ \\
\hline PPADS & 75 puncta, 2 slices & $62 \pm 3 \%$ & 82 puncta, 2 slices & $64 \pm 1 \%$ & $p=0.41$ \\
\hline aßMeATP & 144 puncta, 4 slices & $73 \pm 1 \%$ & 29 puncta, 1 slice & $70 \pm 1 \%$ & $p=0.09$ \\
\hline
\end{tabular}

*, Data is presented as mean \pm SEM. 
accommodate incubation time. For each time-series and Z-stack experiment 22 to 321 puncta from at least 3 slices were analyzed.

\section{Confocal calcium imaging}

Live cell confocal imaging was performed as previously described on olfactory epithelial slices (400-500 $\mu \mathrm{m})$ [26] and/or $\mathrm{P}_{2} \mathrm{X}_{2}$-transfected HEK 293 cells $(\mathrm{n}=$ at least 3 slices/coverslips) using an Olympus Fluoview 1000 system. OE slices and $\mathrm{P}_{2} \mathrm{X}_{2}$-transfected HEK 293 cells were loaded with fluo-4 AM (18 uM; Invitrogen, Carlsbad, CA, USA) for 90 and 30 minutes, respectively, as previously described [26]. Time series experiments were performed collecting $256 \times 128$ pixel images at $0.7 \mathrm{~Hz}$ for slices and $\geq 1 \mathrm{~Hz}$ for HEK-293 cells. HEK-293 cells were recorded for 10 minutes as pilot experiments showed that these cells always responded to ATP application within this time frame. When using OE slices, experiments were performed by sequentially superfusing purinergic receptor agonists in a randomized order that differed from slice to slice. The fluorometric signals obtained are expressed as relative fluorescence $(\mathrm{F})$ change, $\Delta \mathrm{F} / \mathrm{F}=\left(\mathrm{F}-\mathrm{F}_{0}\right) / \mathrm{F}_{0}$, where $\mathrm{F}_{0}$ is the basal fluorescence level (mean $\mathrm{F}$ of first 10 frames). Increases in fluorescence $10 \%$ above baseline fluorescence fluctuations were considered responses. Only cells that responded to a final ATP application were included in the data analysis and only responses were included in the analysis for peak height determination.

\section{In vivo study}

Neonatal mice (post-natal day 1 ) were instilled intranasally with $10 \mu \mathrm{l}$ saline solution \pm Clostridium difficile toxin A $(1 \mathrm{nM})$. Each mouse received a re-instillation of saline \pm Clostridium difficile toxin A every 24 hrs. Mice received an intraperitoneal injection of bromodeoxyuridine (BrdU; $180 \mathrm{mg} / \mathrm{kg}$ total) at 66,68 and $70 \mathrm{~h}$ and tissue was collected at $72 \mathrm{hrs}$ by decapitation. The retronasal passage was flushed with $4 \%$ paraformaldehyde (PFA) in $0.1 \mathrm{M}$ phosphate-buffered saline (PBS) and tissue was stored in $4 \%$ PFA at $4^{\circ} \mathrm{C}$ overnight. Tissue was rinsed in 0.1 M PBS, cryoprotected in a $20 \%$ sucrose solution at $4^{\circ} \mathrm{C}$ overnight, placed in dry ice for $10 \mathrm{~min}$, wrapped in parafilm and foil, and stored at $-80^{\circ} \mathrm{C}$ until sectioning. Cryostat sections $(20 \mu \mathrm{m})$ were collected on superfrost plus slides (Electron Microscopy Sciences, Hatfield, PA), and stored at $-20^{\circ} \mathrm{C}$.

\section{Immunohistochemistry}

To perform BrdU immunohistochemistry, tissue sections were warmed to room temperature, rehydrated with 0.1 M PBS, permeabilized with $0.3 \%$ Triton-X in $0.1 \mathrm{M}$ PBS and then blocked with $10 \%$ normal donkey serum (NDS) diluted in $0.1 \mathrm{M}$ PBS for $1 \mathrm{~h}$ at room temperature. To denature DNA, sections were incubated in filtered $2 \mathrm{M}$ $\mathrm{HCl}$ for $30 \mathrm{~min}$ at $65^{\circ} \mathrm{C}$. Tissue was treated with rat anti-
BrdU monoclonal primary antibody (1:100 in 10\% NDS; Abcam, Cambridge MA) at $4^{\circ} \mathrm{C}$ overnight. Tissue sections were treated with donkey anti-rat FITC secondary antibody (1:200 in $0.3 \%$ Triton X-100; Jackson ImmunoResearch Laboratories, West Grove, PA) for $2 \mathrm{hrs}$ at $37^{\circ} \mathrm{C}$, rinsed with $0.1 \mathrm{M}$ PBS and mounted with Vectashield (Vector Laboratories, Burlingame, CA). A Nikon Eclipse 2000-U microscope equipped with an xcite $120^{\mathrm{Tm}}$ fluorescence illumination system was used to visualize immunoreactivity. The total number of BrdU ${ }^{+}$cells was counted over a measured length of the olfactory epithelium lining the turbinates of each section. BrdU ${ }^{+}$cells found in the apical region of the turbinates were also counted. $n=15,17,19$ sections from 3 and 4 animals for control and $1 \mathrm{nM}$ toxin A, respectively.

All other immunohistochemistry was performed by rehydrating paraformaldehyde-fixed tissue sections from adults $(20 \mu \mathrm{m})$ collected as previously described [9] with $0.1 \mathrm{M}$ PBS with $0.1 \%$ triton X-100 for 20 min, and blocked with bovine serum albumin (BSA) (3\%, P2X7; 5\%, SNAP 23) in 0.1 M PBS with triton X-100 for $60 \mathrm{~min}$. Primary antibodies were added to tissue sections overnight. Goat-anti $\mathrm{P}_{2} \mathrm{X}_{7}$ antibody (1:20; Santa Cruz, CA) and rabbit-anti SNAP 23 + goat-anti olfactory marker protein (OMP) (1:200; Abcam, Cambridge, MA and 1:250, Waco Chemicals, Plano, TX, respectively) antibodies were made in $1 \% \mathrm{BSA}$ in $0.1 \mathrm{M}$ PBS. FITC-conjugated donkey antirabbit or donkey anti-goat antibody (1:200; Jackson ImmunoResearch Labs, West Grove, PA) was applied for $1 \mathrm{hr}$ at room temperature. Sections were then washed and mounted in Vectashield mounting medium for fluorescence (Vector Labs, Burlingame, CA) and visualized on an Olympus FluoView 1000 laser scanning confocal microscope. FITC dye was excited at $488 \mathrm{~nm}$ and low pass filtered at 505-525 $\mathrm{nm}$. Antibody specificity was tested by omitting the primary antibodies. Additionally, a peptide neutralization protocol was performed by combining $\mathrm{P}_{2} \mathrm{X}_{7}$ antibody $(0.04 \mathrm{mg} / \mathrm{ml})$ with a $10-20$ fold excess of the immunizing peptide $(0.4-0.8 \mathrm{mg} / \mathrm{ml})$. No immunoreactivity was observed in any of the controls.

\section{Statistical analysis}

We employed either the Student's t-test or a one-way ANOVA followed by Bonferroni's planned comparison test without correction for multiple comparisons to compare data sets, as indicated in text, using Prism Software 5.01 (Graphpad Software; San Diego, CA). A value of $p<0.05$ was considered statistically significant.

\section{Competing interests}

The authors declare that they have no competing interests.

\section{Author's contributions}

SH participated in the experimental design, carried out all the ATP release experiments, the confocal calcium imaging study using HEK-293 cells and the in vivo proliferation study, and drafted the manuscript. CJ carried out the 
immunohistochemistry. CCH conceived of the study, participated in its design and coordination, carried out the confocal calcium imaging study using neonatal OE slices, and wrote the manuscript. All authors read and approved the final manuscript.

\section{Acknowledgments}

Authors thank Sean W. Crudgington and Benjamin D. Clark for their excellent technical assistance. P2X $\mathrm{X}_{2}$-transfected cells were generously provided by Dr. James J. Galligan from Michigan State University. This work was supported by NIH NIDCD DC006897.

Received: 14 October 2011 Accepted: 09 April 2012

Published: 28 May 2012

\section{References}

1. Burnstock G: Physiology and pathophysiology of purinergic neurotransmission. Physiol Rev 2007, 87(2):659-797.

2. Huang Y, Maruyama Y, Dvoryanchikov G, Pereira E, Chaudhari N, Roper S: The role of pannexin 1 hemichannels in ATP release and cell-cell communication in mouse taste buds. Proc Natl Acad Sci USA 2007, 104(15):6436-6441.

3. Romanov RA, Rogachevskaja OA, Bystrova MF, Jiang P, Margolskee RF, Kolesnikov SS: Afferent neurotransmission mediated by hemichannels in mammalian taste cells. EMBO J 2007, 26(3):657-667.

4. Sabirov RZ, Dutta AK, Okada Y: Volume-dependent ATP-conductive large-conductance anion channel as a pathway for swelling-induced ATP release. J Gen Physiol 2001, 118(3):251-266.

5. Tritsch NX, Yi E, Gale JE, Glowatzki E, Bergles DE: The origin of spontaneous activity in the developing auditory system. Nature 2007, 450(7166):50-55.

6. Anselmi F, Hernandez VH, Crispino G, Seydel A, Ortolano S, Roper SD, Kessaris N, Richardson W, Rickheit G, Filippov MA, et al: ATP release through connexin hemichannels and gap junction transfer of second messengers propagate $\mathrm{Ca} 2+$ signals across the inner ear. Proc Natl Acad Sci USA 2008, 105(48):18770-18775.

7. Lahne M, Gale JE: Damage-induced cell-cell communication in different cochlear cell types via two distinct ATP-dependent Ca waves. Purinergic Signal 2010, 6(2):189-200.

8. Kurth-Nelson ZL, Mishra A, Newman EA: Spontaneous glial calcium waves in the retina develop over early adulthood. J Neurosci 2009, 29(36):11339-11346.

9. Jia C, Doherty JD, Crudgington S, Hegg CC: Activation of purinergic receptors induces proliferation and neuronal differentiation in Swiss Webster mouse olfactory epithelium. Neuroscience 2009, 163(1):120-128.

10. Jia C, Roman C, Hegg CC: Nickel sulfate induces location-dependent atrophy of mouse olfactory epithelium: protective and proliferative role of purinergic receptor activation. Toxicol Sci 2010, 115(2):547-556.

11. Jia C, Sangsiri S, Belock B, lqbal T, Pestka JJ, Hegg CC: ATP mediates neuroprotective and neuroproliferative effects in mouse olfactory epithelium following exposure to satratoxin $\mathrm{G}$ in vitro and in vivo. Toxicol Sci 2011, 124(1):169-178.

12. Jia C, Cussen AR, Hegg CC: ATP differentially upregulates fibroblast growth factor 2 and transforming growth factor alpha in neonatal and adult mice: effect on neuroproliferation. Neuroscience 2011, 177:335-346.

13. Jia C, Hegg CC: NPY mediates ATP-induced neuroproliferation in adult mouse olfactory epithelium. Neurobiol Dis 2010, 38(3):405-413.

14. Kanekar S, Jia C, Hegg CC: Purinergic receptor activation evokes neurotrophic factor neuropeptide $Y$ release from neonatal mouse olfactory epithelial slices. J Neurosci Res 2009, 87(6):1424-1434.

15. Abraham EH, Prat AG, Gerweck L, Seneveratne T, Arceci RJ, Kramer R, Guidotti G, Cantiello HF: The multidrug resistance (mdr1) gene product functions as an ATP channel. Proc Nat Acad Sci USA 1993, 90(1):312-316.

16. Schwiebert EM: ABC transporter-facilitated ATP conductive transport. Am J Physiol 1999, 276(1 Pt 1):C1-C8.

17. Manzini I, Schild D: Multidrug resistance transporters in the olfactory receptor neurons of Xenopus laevis tadpoles. JPhysiol 2003, 546(Pt 2):375-385.

18. Delay RJ, Dionne VE: Coupling between sensory neurons in the olfactory epithelium. Chem Senses 2003, 28(9):807-815.

19. Miragall F, Hwang TK, Traub O, Hertzberg EL, Dermietzel R: Expression of connexins in the developing olfactory system of the mouse. J Comp Neurol 1992, 325(3):359-378.
20. Zhang $C$, Finger TE, Restrepo D: Mature olfactory receptor neurons express connexin 43. J Comp Neurol 2000, 426(1):1-12.

21. Zhang C, Restrepo D: Expression of connexin 45 in the olfactory system. Brain Res 2002, 929(1):37-47.

22. Zhang C, Restrepo D: Heterogeneous expression of connexin 36 in the olfactory epithelium and glomerular layer of the olfactory bulb. J Comp Neurol 2003, 459(4):426-439.

23. Bruzzone R, Hormuzdi SG, Barbe MT, Herb A, Monyer H: Pannexins, a family of gap junction proteins expressed in brain. Proc Natl Acad Sci USA 2003, 100(23):13644-13649.

24. Gayle S, Burnstock G: Immunolocalisation of P2X and P2Y nucleotide receptors in the rat nasal mucosa. Cell Tissue Res 2005, 319(1):27-36.

25. Hassenklover T, Kurtanska S, Bartoszek I, Junek S, Schild D, Manzini I: Nucleotideinduced $\mathrm{Ca}(2+)$ signaling in sustentacular supporting cells of the olfactory epithelium. Glia 2008, 56(15):1614-1624

26. Hegg CC, Greenwood D, Huang W, Han P, Lucero MT: Activation of purinergic receptor subtypes modulates odor sensitivity. J Neurosci 2003, 23(23):8291-8301.

27. Sorensen CE, Novak I: Visualization of ATP release in pancreatic acini in response to cholinergic stimulus. Use of fluorescent probes and confocal microscopy. J Biol Chem 2001, 276(35):32925-32932.

28. Sudhof TC: The synaptic vesicle cycle. Annu Rev Neurosci 2004, 27:509-547.

29. Ralevic V, Burnstock $\mathrm{G}$ : Receptors for purines and pyrimidines. Pharmacol Rev 1998, 50(3):413-492.

30. Pelegrin $P$, Surprenant $A$ : Pannexin-1 mediates large pore formation and interleukin-1 beta release by the ATP-gated P2X7 receptor. EMBO J 2006 25(21):5071-5082.

31. Ma W, Hui H, Pelegrin P, Surprenant A: Pharmacological characterization of pannexin-1 currents expressed in mammalian cells. J Pharmacol Exp Ther 2009, 328(2):409-418.

32. Suadicani SO, Brosnan CF, Scemes E: P2X7 receptors mediate ATP release and amplification of astrocytic intercellular $\mathrm{Ca} 2+$ signaling. $J$ Neurosci 2006, 26(5):1378-1385.

33. Silverman W, Locovei S, Dahl G: Probenecid, a gout remedy, inhibits pannexin 1 channels. Am J Physiol Cell Physiol 2008, 295(3):C761-C767.

34. Waseem TV, Lapatsina LP, Fedorovich SV: Influence of integrin-blocking peptide on gadolinium- and hypertonic shrinking-induced neurotransmitter release in rat brain synaptosomes. Neurochem Res 2008, 33(7):1316-1324.

35. Spray DC, Ye ZC, Ransom BR: Functional connexin "hemichannels": a critical appraisal. Glia 2006, 54(7):758-773.

36. De Lorenzo S: Presynaptic inhibition of spontaneous acetylcholine release mediated by $\mathrm{P} 2 \mathrm{Y}$ receptors at the mouse neuromuscular junction. Neuroscience 2006, 142(1):71-85.

37. Hegg CC, Lucero MT: Purinergic receptor antagonists inhibit odorant-induced heat shock protein 25 induction in mouse olfactory epithelium. Glia 2006, 53(2):182-190.

38. Hassenklöver T, Schwartz P, Schild D, Manzini I: Purinergic signaling regulates cell proliferation of olfactory epithelium progenitors. Stem Cells 2009, 27(8):2022-2031.

39. Simpson SA, Alexander DJ, Reed CJ: Induction of heat shock protein 70 in rat olfactory epithelium by toxic chemicals: in vitro and in vivo studies. ArchToxicol 2005, 79(4):224-230

40. Veggetti M, Muchnik S, Losavio A: Effect of purines on calcium-independent acetylcholine release at the mouse neuromuscular junction. Neuroscience 2008, 154(4):1324-1336.

41. Braun N, Zimmermann H: Association of ecto-5'-nucleotidase with specific cell types in the adult and developing rat olfactory organ. J Comp Neurol 1998, 393(4):528-537.

42. Di VF, Steinberg TH, Silverstein SC: Inhibition of Fura-2 sequestration and secretion with organic anion transport blockers. Cell Calcium 1990, 11(2-3):57-62.

43. Decker DA, Galligan JJ: Cross-inhibition between nicotinic acetylcholine receptors and $\mathrm{P} 2 \mathrm{X}$ receptors in myenteric neurons and HEK-293 cells. Am J Physiol Gastrointest Liver Physiol 2009, 296(6):G1267-G1276.

44. Hegg CC, Irwin M, Lucero MT: Calcium store-mediated signaling in sustentacular cells of the mouse olfactory epithelium. Glia 2009, 57(6):634-644.

doi:10.1186/1471-2202-13-53

Cite this article as: Hayoz et al:: Mechanisms of constitutive and ATP-evoked ATP release in neonatal mouse olfactory epithelium. BMC Neuroscience 2012 13:53. 